\title{
Making Sense of a Trial Maths Intervention Program for Students with Disability in Australia: Interim Report
}

\author{
Bronwyn Ewing \\ School of Curriculum, Queensland University of Technology, Australia
}

Copyright $(2016$ by authors, all rights reserved. Authors agree that this article remains permanently open access under the terms of the Creative Commons Attribution License 4.0 International License

\begin{abstract}
Success in primary and secondary school mathematics is becoming increasingly important to today's teachers, students, parents and employment providers in Australia. Mathematics is viewed as high status and essential for a range of employment opportunities. The Disability Standards for Education [1] and the Australian Curriculum, Reporting and Assessment Authority [2] underscore the rights of students with disability to access the curriculum on the same basis as students without disability. They are entitled to rigorous, relevant and engaging learning opportunities drawn from Australian Curriculum content on the same basis as students without disability. Taking this context into account, this paper provides a work-in-progress report about a two year mathematics intervention project conducted in twelve special schools (Preparatory to Year 12) in Queensland, Australia. The purpose of the project was to address an important problem related to the mathematics achievement of students with disability. It aimed to build the capacity of the schools and teachers in relation to teaching mathematics to their students and to identify and make sense of the intervening program's impact. It combined two approaches, appreciative inquiry [3] and action research [4] to monitor schools' planning for change. Interim findings demonstrated that teachers were concerned about their students' underachievement in mathematics and how to assess this and that multi-sensory forms of teaching and learning advocated in the program increased students' engage and performance. The adoption of reflective teacher portfolios demonstrated their usefulness for engaging teachers in appreciative inquiry and action research to monitor the implementation and impact of the program in their schools and classrooms.
\end{abstract}

Keywords Special Education, Mathematics Intervention Program, Students with Disability, Multi-sensory Learning

\section{Introduction}

Education is an anti-poverty strategy to protective children and young people with disability from disadvantage yet, in Australia they are less likely to access an education that provides the best possible education outcomes. They typically have low levels of literacy and numeracy knowledge and skills and, as a consequence, a future seriously compromised. Progression from childhood is highly likely to be that of young people with disability and subsequently "adults with disability who have greatly reduced life opportunities" [5 p35]. This progression leads to reduced economic security, reinforces society's low expectations of people with disability and underlies a life entrenched in a cycle of poverty and disadvantage [6]. This outcome is an immediate problem facing Australia and is in critical need of addressing.

A poor education is one of the key reasons why the economic and social participation rate of Australians with disabilities is so low. Young people with disability are less likely to have completed Year 12 and are less likely to hold a post-school qualification [6, 7]. They are more likely to be unemployed and have significantly less income than others in the community. When compared against the OECD $[6,8]$ average, the rate of employment of people with disabilities in Australia is low. They are half as likely to be employed when compared with people without disability and are at high risk of poverty. Indeed, Australia's poverty risk, that is, people with disability compared to people without a disability, is 2.7 against the OECD average of 1.6. Forty-five percent of Australians with disabilities live in, or near, the poverty line [9]; more than double the OECD average of 22 percent $[6,8]$. Their preparation in literacy and numeracy through formal education for post-school life in activities such as employment, vocational training or higher education is critical to moving towards an independent adult life and breaking the cycle of such disadvantage.

Tied to this complexity is research evidence reporting that teachers, including special education teachers, lack sufficient mathematics content knowledge and pedagogical content knowledge $[10,11]$. Currently in Australia, students with intellectual impairment and with additional disabilities struggle to learn essential concepts and skills at primary and 
secondary levels of schooling. Whilst there is a strong commitment from teachers to support students with learning mathematics, their preparation and capacity to teach it is of current concern [12]. Research indicates that many have a poor understanding of teaching and learning for specific content areas, resulting in an overemphasis on procedural and low level skills and limited use of multi-modal and multi-sensory instruction that more fully engages students' development of conceptual understandings of use of mathematics ideas, equipment and materials $[12,13]$. This concern provides the context for the mathematics intervention program used in the study. Whilst there are interventions widely endorsed for reading there is much less evidence for mathematics although interest is gaining in mathematics [14].

\section{The Intervention Program}

The intervention program was designed for teachers (Preparatory to Year 12) who teach students underperforming in mathematics in special education schools in Queensland. Titled Yumi Deadly Maths, it was originally developed by a team of researchers at the Queensland University of Technology (QUT) [15-18] and focused on schools with high Aboriginal and Torres Strait Islander students who were identified by their classroom teachers as underperforming in mathematics. More recently the program has been used in classrooms in special schools in Queensland and Victoria. Funding for the program that is the basis of this report was derived from twelve participating schools through the State Schools Queensland, Great Results Guarantee, a four-year funding initiative to improve student outcomes [19]. This program passes on to the schools, funding provided by the Australian Government's Students First initiative [20]. The program is underpinned by Payne and Rathmell's [21] theory of mathematics learning and Bruner's [22] three modes of representation (enactive, iconic and symbolic) both are represented through a four phased instructional cycle, reality, abstraction, mathematics and reflection (RAMR).

The RAMR instructional cycle has four phases of learning. Each phase builds on from and is connected to the previous phase to stimulate and encourage conceptual understanding as well as automaticity and fluency. The four phases of the RAMR instructional cycle include the following:

1. $\mathrm{R}=$ learning through awareness of local cultural and environmental knowledge and experiences about the idea; constructing and participating in kinaesthetic activities that introduce the idea and are relevant in terms of knowledge and experience.

2. $\mathrm{A}=$ learning through the process of abstracting the idea from reality and representing it using the body-hands-mind; creating representations of it using the hands-body-mind-multisensory experiences, materials, language and symbols.

3. $\mathrm{M}=$ learning through enabling the appropriation of formal language and symbols for mathematical ideas; practicing to become familiar with all aspects of the idea.

4. $\mathrm{R}=$ learning through connecting the idea back to reality enabling the validation and justification of own knowledge; using reflective strategies-flexibility, generalising, reversing, and changing parameters.

The phases are interconnected and not viewed as discrete and isolated throughout instruction. Teachers' and students' explicit connections from one phase to another are essential for learning concepts and skills. Without this awareness students, are likely to feel as though they are memorising isolated procedures that have little connection to what they are learning.

There are several benefits for teachers who use the instructional cycle for teaching mathematics to students with disability. First, the RAMR instructional cycle provides multimodal forms of learning and opportunities for students to see their realities of mathematics in everyday life, orienting themselves to those ideas and the context from which they arise. These forms of learning include seeing, hearing, touching and muscle movement-visual, auditory, kinaesthetic, and tactile learning aids memory and retrieval skills $[13,23]$. Second, students with disability and those who struggle because of other factors have multiple characteristics that affect their ability to learn mathematics. These characteristics include impulsivity, language deficits, hyperactivity and lack of prior knowledge, memory difficulties and motivation problems. They create the need for connecting the importance of content to everyday life to increase motivation [12]. Third, body movement and manipulation of materials in the reality and abstraction phases allows students to represent their reality using their hands, body and mind, materials, symbols and language in a range of ways to create meaning [21]. These phases allow students to recognise new experiences as having the similarities of an already formed experience [24]. Fourth, through this process, the construction of knowledge and meaning making becomes a necessary condition for mathematics learning [25]. Finally, the setting of problems back in reality enables students to validate, justify and generalise their own knowledge so that they can extend on ideas.

\section{Methodology}

The project adopted a collaborative approach which has horizontal and vertical dimensions. The vertical dimension involved exchanges of views at different levels, e.g., between twelve schools and principals and forty-eight teachers. The project facilitated the engagement of two teachers to actively champion and promote the project across the twelve schools. Through regular communicative tools such as email, telephone conferences and intensive face-to-face PL meetings, the project team and participants, regularly collaborated across all aspects of the project. These 
strategies contributed to the "population of values" [26], influencing participants and other teachers horizontally within schools. Given the substantial significance of the issue that this project aimed to address, it promoted ways for bringing people together to participate in organisational learning and change, knowledge sharing and making sense of impact. It advocated considerable dialogue about whether the proposed change was sustainable, who benefited and, would other supporters of the project like it-all of these elements personified views about priority values.

The project adopted an appreciative inquiry (AI) approach to monitoring and evaluating impact and interconnects with the change process for schools, principals and teachers [3, 27]. AI has been identified as a reconfiguration of action research within organisational settings such as schools. It is described as a strategic planning model, participatory and a system-wide approach that seeks to discover what works based on solutions that exist currently within organisations such as the schools.

Participating schools, principals and teachers

The twelve participating schools were from regional and metropolitan areas of Queensland. The participants in the project included twelve Principals and forty-eight teachers. Principals were required to attend the first day of workshops in 2014 and 2015; this was to ensure that they were fully aware of the program, its intentions and purpose. As they were responsible for distributing the funding the program, building their capacity about it and the change processes involved, including the demands of teachers, were important to its successful implementation. The Principals, in conjunction with individual schools' leadership teams selected four highly motivated teachers from a range of school year levels to participate and lead the program in their schools. Two project champions were nominated by the Principals' leadership team to guide the overarching implementation of the project.

The professional learning program and data collection strategies

There were several elements to the professional learning (PL) program, including six days over two years of PL workshop attendance, school visits, resource provision and action research support. The timeline and strand focus (Table 1) were from the Australian Mathematics Curriculum [28] and shows the progression of the PL program. The project expected a commitment from participants to participate and engage in PL workshop activities (2014-2015) that were held at QUT as well as lesson modelling and PL held at school sites. They were strongly encouraged to discuss, network and strategise the continued implementation of the program in their schools in 2014-2015 and beyond. Critical to this process were discussions about strategies that focused on leading and supporting their teachers through change and making sense of this process in their schools.

Table 1. Timeline for professional learning program

\begin{tabular}{|l|l|l|}
\hline & \multicolumn{1}{|c|}{ Round 1 } & \multicolumn{1}{c|}{ Round 2 } \\
\hline 2014 & $\begin{array}{l}\text { Pre-foundational process; } \\
\text { Number; Action research }\end{array}$ & $\begin{array}{l}\text { School change and leadership; } \\
\text { Operations; Measurement }\end{array}$ \\
\hline 2015 & Geometry & $\begin{array}{l}\text { Algebra; statistics and } \\
\text { probability }\end{array}$ \\
\hline
\end{tabular}

As part of participation in PL workshops Principals and teachers were asked to complete a PL evaluation, questionnaire and survey. The evaluation focused on rating the different sessions presented and asked for overall comments. Table 2 provides a snapshot of the qualitative feedback from the sessions. 
Table 2. Examples of qualitative feedback from sessions

\begin{tabular}{|c|c|c|c|c|}
\hline \multicolumn{5}{|c|}{ Q1. What aspect/s of the day's PD Program did you find most useful and why? } \\
\hline $\begin{array}{l}\text { The pre foundational } \\
\text { processes, RAMR cycle, } \\
\text { big ideas -- can definitely } \\
\text { see how we can } \\
\text { implement this in our } \\
\text { school. }\end{array}$ & $\begin{array}{l}\text { Body Hand Mind - LOVED } \\
\text { RAMR. Linking maths } \\
\text { learning to the students reality } \\
\text { is so important as our kids } \\
\text { have difficulty generalising }\end{array}$ & $\begin{array}{l}\text { Learning about body } \\
\text { hand mind. Love this } \\
\text { concept for teaching. }\end{array}$ & $\begin{array}{l}\text { Opportunities to } \\
\text { engage with materials } \\
\text { Reflection and group } \\
\text { planning/discussion. }\end{array}$ & $\begin{array}{l}\text { The Pre-foundational process, } \\
\text { RAMR framework. }\end{array}$ \\
\hline \multicolumn{5}{|c|}{$\begin{array}{l}\text { Q2. Please comment on the extent that the YuMi Deadly Maths program, pre-foundational processes and the RAMR framework might assist you } \\
\text { when teaching mathematics? }\end{array}$} \\
\hline $\begin{array}{l}\text { Assists in my knowledge } \\
\text { of pre-foundational } \\
\text { processes - particularly } \\
\text { useful for students in } \\
\text { General Capabilities }\end{array}$ & $\begin{array}{l}\text { It pushes my thinking to } \\
\text { body/hand/mind activities } \\
\text { prior to using counters and } \\
\text { written numbers. }\end{array}$ & $\begin{array}{l}\text { It will help to keep focus } \\
\text { on math and math } \\
\text { concepts. The RAMR } \\
\text { frame will help to } \\
\text { structure planning and } \\
\text { focus. }\end{array}$ & $\begin{array}{l}\text { Great framework that } \\
\text { links very clearly with } \\
\text { the current teaching } \\
\text { and learning cycle we } \\
\text { are using to plan. }\end{array}$ & $\begin{array}{l}\text { The framework is supportive. I } \\
\text { feel that with it not being } \\
\text { overly prescriptive however } \\
\text { clear in the concepts I can } \\
\text { incorporate the movement } \\
\text { ideas. }\end{array}$ \\
\hline \multicolumn{5}{|c|}{$\begin{array}{l}\text { Q3. How have the PL workshops assisted with building your confidence with teaching maths and gradually releasing the use of textbooks, } \\
\text { worksheets and whiteboard? }\end{array}$} \\
\hline $\begin{array}{l}\text { It's helped me realise that } \\
\text { I already do some hand } \\
\text { and body activities. Also } \\
\text { gave me ideas for body } \\
\text { and hand activities. }\end{array}$ & $\begin{array}{l}\text { Making maths engaging } \\
\text { through lots of body activities } \\
\text { exploring maths concepts. }\end{array}$ & $\begin{array}{l}\text { I have developed a lot of } \\
\text { confidence with teaching } \\
\text { maths and will be } \\
\text { releasing the use of } \\
\text { worksheets etc. }\end{array}$ & $\begin{array}{l}\text { It was great for 'our } \\
\text { school' to write a plan. }\end{array}$ & $\begin{array}{l}\text { Actually seeing the ideas in } \\
\text { practice makes me feel like I } \\
\text { can imitate what I saw till I am } \\
\text { comfortable to create my own } \\
\text { ideas and full lesson plans. }\end{array}$ \\
\hline \multicolumn{5}{|c|}{ Q4. What topics/ideas/training do you believe would be useful to focus on in future workshops? } \\
\hline $\begin{array}{l}\text { Assessment for the } \\
\text { cohort that we get in } \\
\text { special schools. }\end{array}$ & $\begin{array}{l}\text { Having principals involved in } \\
\text { all planning sessions. }\end{array}$ & $\begin{array}{l}\text { Assessment instruments } \\
\text { and data analysis (shared } \\
\text { among schools). }\end{array}$ & $\begin{array}{l}\text { More of the practical } \\
\text { resources and teaching } \\
\text { strategies for teaching } \\
\text { the big ideas and } \\
\text { concepts. }\end{array}$ & $\begin{array}{l}\text { Sharing how schools } \\
\text { implemented Action Steps. } \\
\text { What works, what doesn't and } \\
\text { trends. }\end{array}$ \\
\hline
\end{tabular}

The questionnaire focused on demographic information, for example, formal qualifications, students' mathematics areas of difficulty. The survey focused on practices used in classrooms.

Schools were provided with $1 \times 1$-day visit per year (2 days across 2 years) to support teachers through lesson modelling, observations and critique of practice to develop knowledge and understanding of the learning needs of students with disabilities. Participating schools were provided with supporting documents about the approach to teaching mathematics and resources on how to implement this approach.

Participants were trained in action research and inquiry to monitor their progress with the implementation of the program. To do this, participants were workshopped on how to monitor their activities in their schools and gather data by way of a reflective portfolio that contained: (a) teaching plans (RAMR cycle), (b) student pre-post test results, and (c) analysis of teaching plans and student results.

Analysis: Making sense of the intervening program's impact

Building the capacity of the schools and teachers in relation to teaching mathematics to their students was central to the project. Because of the scope of the project, the analysis will draw on elements of the questionnaire and examples from the portfolios.

\section{The Questionnaire}

A questionnaire was administered to participants at the Round 1 workshops $(N=60)$ with 93 percent response rate $(n=56)$ so as to build knowledge about the participants. A range of questions focused on demography and identifying background variables including diversity of school community, teacher qualifications, number of years at previous/present school and views about teaching and student learning.

Students attending the participating special schools included students with intellectual impairment and with additional disabilities (Autistic Spectrum Disorder, Physical Impairment, Hearing Impairment and/ or vision Impairment). Their needs were identified by the teachers as complex and therefore were not always met through procedural approaches to teaching mathematics. Coupled with this complexity was the range of cultural and social groupings. Of significance was that nearly 72 percent of the student population of the 12 schools were low socioeconomic, English as a Second Language and refugee. The challenges that the schools faced in responding to such diversity included trying to support students who experienced multiple and cumulative disadvantages because of their disability and belonging to a number of disadvantaged groups.

The results from the teacher questionnaire indicated that the strand of Number was strongly identified as an area of student difficulty. Of significance was the large percentage attributed to Number $(n=68 \%)$ (identified by participants as before and after, more than/less than, trust the count, value of numbers, number formation, teen numbers, place value, renaming/regrouping). If we include "other" with this portion, nearly 97 percent of difficulties are associated with 
this topic (and including language, multistep problems, generalisation, abstract ideas, conservation and comparing). This information is particularly significant for the project and teachers and highlights a range of issues for such a diverse group of learners. It creates a challenging situation for their teachers and their expertise with how to address the issues. Of the participants who completed the questionnaire $(n=56)$, figure 1 documents the highest university qualifications gained.

Participants were asked about the their highest university qualification, specialisations, year of completion, perceptions about mathematics, approach to teaching mathematics, role in school for implementing PL program and students mathematical areas of difficulty. Of significance is that of the participants who completed the questionnaire $98 \%$ have a university qualification ranging from Bachelor of Education to a Graduate Diploma and or Certificate. Of interest $35 \%$ identified as having a qualification in the special education field, for example, Autism studies.

Current data from labour market research on school teachers [29, p. 16-17] reports that $48 \%$ of teachers of special needs in primary school had less than one year of tertiary study in this area. School employers identified that it was difficult to attract teachers with relevant experience in special schools but were willing to compromise to fill their positions with many hiring learning support teachers instead of special education teachers. Reasons applicants were unsuitable included that they did not have specific special education qualifications and lacked experience teaching students with special needs or a particular learning disorder such as autism.

\section{Questionnaire Data: Highest University Qualification}

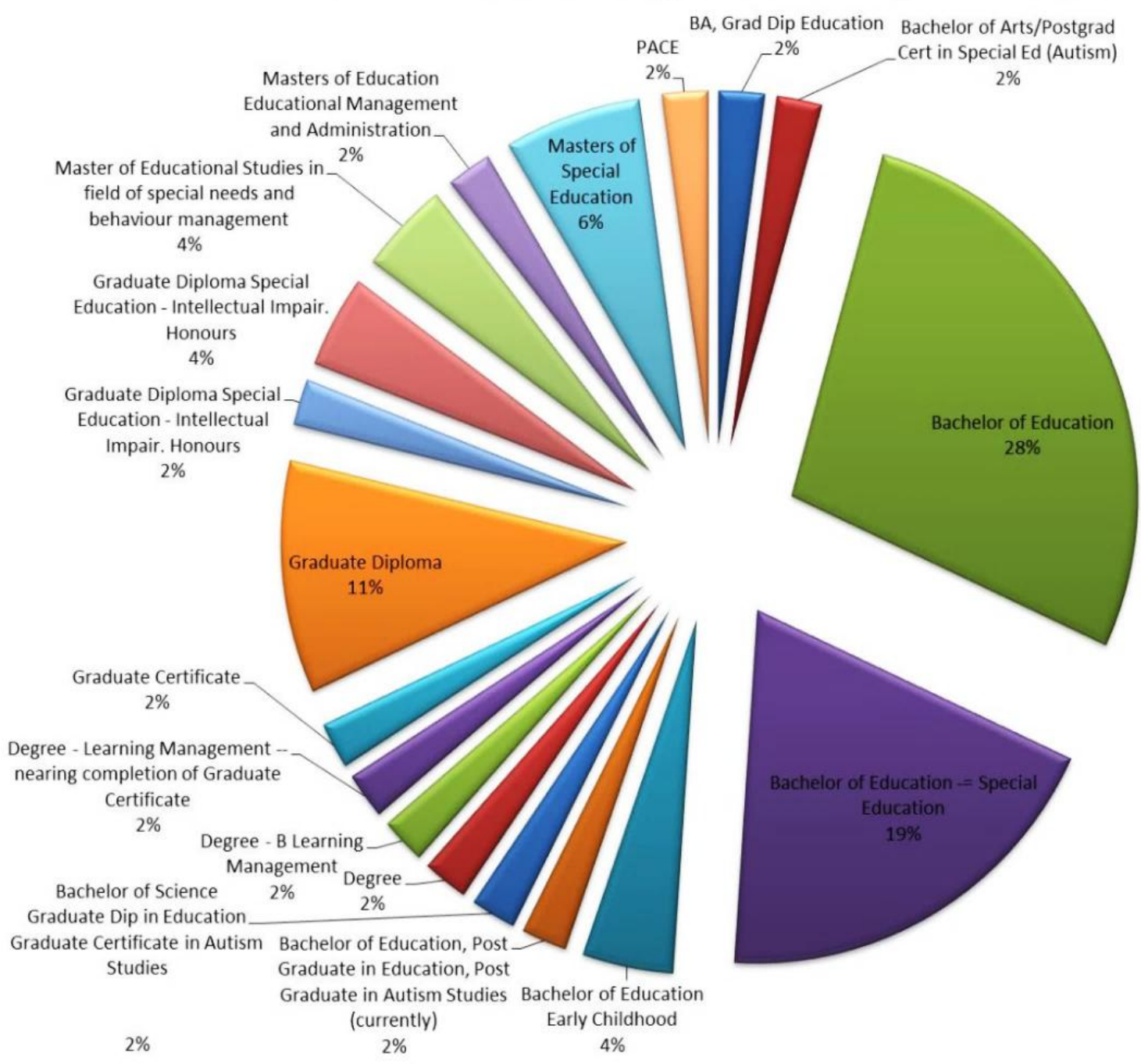

Figure 1. Highest university qualifications of participants 


\section{The Survey}

A Likert scale survey was administered in $2014(n=36)$. It asked several questions related to teachers' practice. A value ( 1 strongly disagree to 5 strongly agree) were assigned to each response allowing for reporting a single average for each response. Table 3 shows the results of the survey.

Table 3. Average agreement with each statement related to teachers' practice 2014 ( 1 =strongly disagree, 5 = strongly agree)

\begin{tabular}{|c|c|}
\hline Items about teachers' practice 2014 & Used in 2014 \\
\hline $\begin{array}{l}\text { 1. I display charts or reference materials that relate to } \\
\text { mathematical concepts I am teaching in my room }\end{array}$ & 3.8 \\
\hline $\begin{array}{l}\text { 2. I link my students' reality (Prior Knowledge) to the } \\
\text { teaching of mathematics }\end{array}$ & 4.1 \\
\hline $\begin{array}{l}\text { 3. I give verbal \& non-verbal feedback to students in } \\
\text { regards to their mathematics learning }\end{array}$ & 4.4 \\
\hline $\begin{array}{l}\text { 4. I ensure that goals for maths are set in my } \\
\text { classroom and that the strategies for improvement are } \\
\text { evident \& understood within the process }\end{array}$ & 3.7 \\
\hline $\begin{array}{l}\text { 5. I connect the students' reality experiences to } \\
\text { abstract the language, represent that reality and being } \\
\text { using symbolic language }\end{array}$ & 3 \\
\hline $\begin{array}{l}\text { 6. I give my students opportunities to use their whole } \\
\text { body, hands \& minds/images }\end{array}$ & 3.6 \\
\hline $\begin{array}{l}\text { 7. I use pre/post testing in my classroom to plan for } \\
\text { future teaching }\end{array}$ & 3.4 \\
\hline $\begin{array}{l}\text { 8. I track to see how students are doing within a } \\
\text { lesson by ' checking-in }\end{array}$ & 4 \\
\hline $\begin{array}{l}\text { 9. The maths concepts that students learn are situated } \\
\text { in reality and guided by the abstraction process }\end{array}$ & 3.6 \\
\hline $\begin{array}{l}\text { 10. I include opportunities for students to critically } \\
\text { reflect on their learning of maths }\end{array}$ & 2.4 \\
\hline $\begin{array}{l}\text { 11. In my maths lessons I guide students with } \\
\text { critically reflecting on their maths learning }\end{array}$ & 3 \\
\hline $\begin{array}{l}\begin{array}{l}\text { 12. I am confident with teaching maths in my } \\
\text { classroom }\end{array} \\
\end{array}$ & 3.4 \\
\hline
\end{tabular}

The results captured a range of item difficulties including critical reflection in mathematics lessons and connecting realistic experiences to abstract language symbolic language. There are reasons for why this might be the case including that student characteristics such as impulsivity, language difficulties, hyperactivity, lack of prior knowledge, memory difficulties and motivation problems may impact on their capacity to reflect on their learning.

Most of the items in the survey were identified as easier to endorse. For example, there was a degree of agreement with statements 2, 3 and 8. Statement 2 (4.1) which focused on the link to reality suggests that the teachers recognised the importance of developing students' awareness of maths ideas in the local environment. Statement 3 (4.4) highlights the importance of providing verbal and non-verbal feedback to students. Feedback is critical to the teaching and learning process [30]. It leads to students recognising their next steps and how to take them. It is underpinned by confidence that every student can improve and it involves every teacher and student reviewing and reflecting on the teaching and learning. These characteristics contrast with assessment that simply tests procedures.

\section{Teachers as Researchers - Reflective Portfolios}

Of the total number of teacher participants in 2014 $(N=48)$ forty-eight portfolios (100\%) from twelve schools were received in Round 1 in 2014. This represented a significant result for the project and in doing so demonstrated the high level of engagement of participants in the project.

The project strongly believes that the successful implementation of the program in the participating schools required participants, as "teacher researchers", to actively engage in conducting collaborative research to learn about their practice, the teaching of mathematics and how students learn from that teaching. As the teachers' trialled ideas with other teachers and their students, their efficacy was shown to increase. Efficacy was a critical factor that emerged from the portfolio data as playing a key role in the process of implementing, trialling and changing their practice.

Efficacy is described in various ways including; the motivation that teachers expended on effort to implement the program and a willingness to set challenging goals and the persistence to see them through. Such ways were evident in the portfolios and influenced their determination and adoption of new approaches to teaching by increasing their willingness to take risks and persist with difficulties and setbacks that came with the implementation and change process [31]. Reflection was a critical element as it was through this process that major themes in the portfolio were identified.

\section{Overarching Themes}

The adoption of reflective portfolios as a research strategy in the project aimed to engage teachers in their own learning and reflective practice as well as that of students. Through this process, teachers could trial new ways of teaching as well as create new professional learning collaborations and believe that they could perform instructionally related tasks that were likely to bring about increased student learning. There were ten overarching themes and relationships identified in the portfolios (Table 4).

Table 4. Themes from reflective portfolios

\begin{tabular}{|c|c|}
\hline $\begin{array}{c}\text { Overarching themes of } \\
\text { portfolios }\end{array}$ & Themes and relationships \\
\hline engage & students/learning \\
\hline general capabilities & students/activity \\
\hline understanding & learning/general capabilities \\
\hline RAMR & $\begin{array}{c}\text { understanding/pre-foundational } \\
\text { processes }\end{array}$ \\
\hline teachers & students/general capabilities \\
\hline pre-foundational processes & engage/activity \\
\hline learning & learning/activity \\
\hline activity & understanding/students \\
\hline mathematics & understanding/engage \\
\hline students & students/engage \\
\hline
\end{tabular}

Of interest, they centred on the major ideas and processes 
presented in the Round 1 workshop in 2014. Of the related themes, there was an obvious focus on the students with correlations to learning, activities, understandings, and engagement.

\section{Identified Steps to Implementing the Program}

The RAMR instructional cycle was not designed as a guarantee that schools with students with disability would achieve accuracy in all areas of the mathematics curriculum. Nor was it a guarantee that once teachers were professionally developed in the program they would be successful in their mathematics instruction. It did however provide teachers with an instructional cycle for incorporating the use of multimodal and multi-sensory forms of teaching and learning. The following seven steps were identified in the portfolios, providing an example of how the program was implemented.

1. identify the mathematics concept to be taught and learned;

2. identify what comes before, what comes after and what connects;

3. identify what local knowledge and previous experiences students have had with the concept and draw students' attention to it using visual, auditory, kinaesthetic and tactile activities;

4. match the concept from students' knowledge and experiences with appropriate multi-sensory experiences, materials and language so that representations can be created using the body hands and mind;

5. match the conceptual representations with formal symbols, signs and language;
6. practice with students and make connections to other maths concepts and student experiences;

7. assist students with applying knowledge to other areas and validating their knowledge.

The steps were found to contribute to how the teachers worked through a sequence to ensure they were addressing key components of the program and adopting multi-modal and multi-sensory forms of teaching and learning which provided flexibility and transferability across the mathematics curriculum. This outcome supports the findings from international research which evidenced improvements in mathematics achievement of students with disability through these forms of teaching and learning [32-34]. The portfolios showed that the teachers could design instructional sequences of mathematics lessons that engaged their students in ways they had never experienced before. An overview of one teacher's, Talina, RAMR planning is shown in figure 2.

Teachers like Talina also reported that the assessment of students was complex and challenging because of the lack of a standardised assessment strategy. For example, Talina's portfolio focused on place value and students who were in their senior final year of schooling and working at a Year 2 level. There were three girls and boys in the class.

To identify what place value knowledge the students had she tested the students using a Cognitive Diagnostic Assessment [17]. She reported that overall the students did not achieve well and demonstrated substantial weaknesses in their place value understandings as can be seen in the examples in Table 5 below.

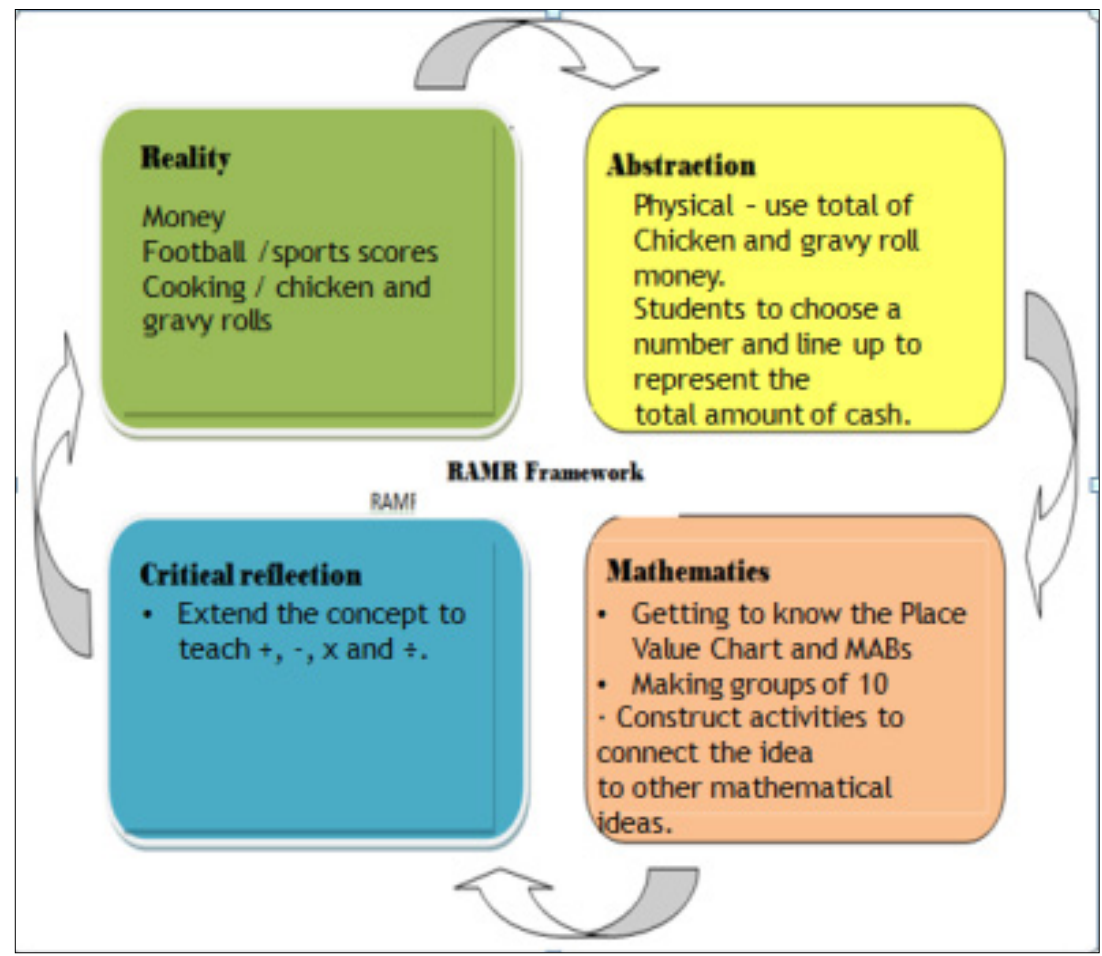

Figure 2. Example of RAMR planning 
Table 5. Examples of students' responses

9. Write the missing numb

a. $54=4$ tens 4

b. $38=4$ tens

c. $\underline{14}=6$ tens 1

d. $\mathbf{O}=1 \operatorname{ten} 10$

e. $63=3$ tens $7 / 4$

\section{PLACE VAORE}

Let's start at the beginning

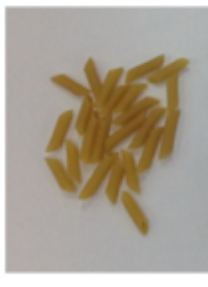

We have ONES can you show me 3 ONES, 8 ONES, 9 ONES?

What happens when we get more than 9 ?
9. Write the missing numbers:

a. $54=4$ tens fir ones

b. $38=B_{\text {tens }} 18$ ones

c. $\ldots$ - $=6$ tens 17 ones

d. $\ldots=1$ ten 10 ones

e. $63=3$ tens ones

f. _ $=0$ tens 37 ones

CAN WE BUNDLE THOSE ONES TO MAKE TENS? ? S?
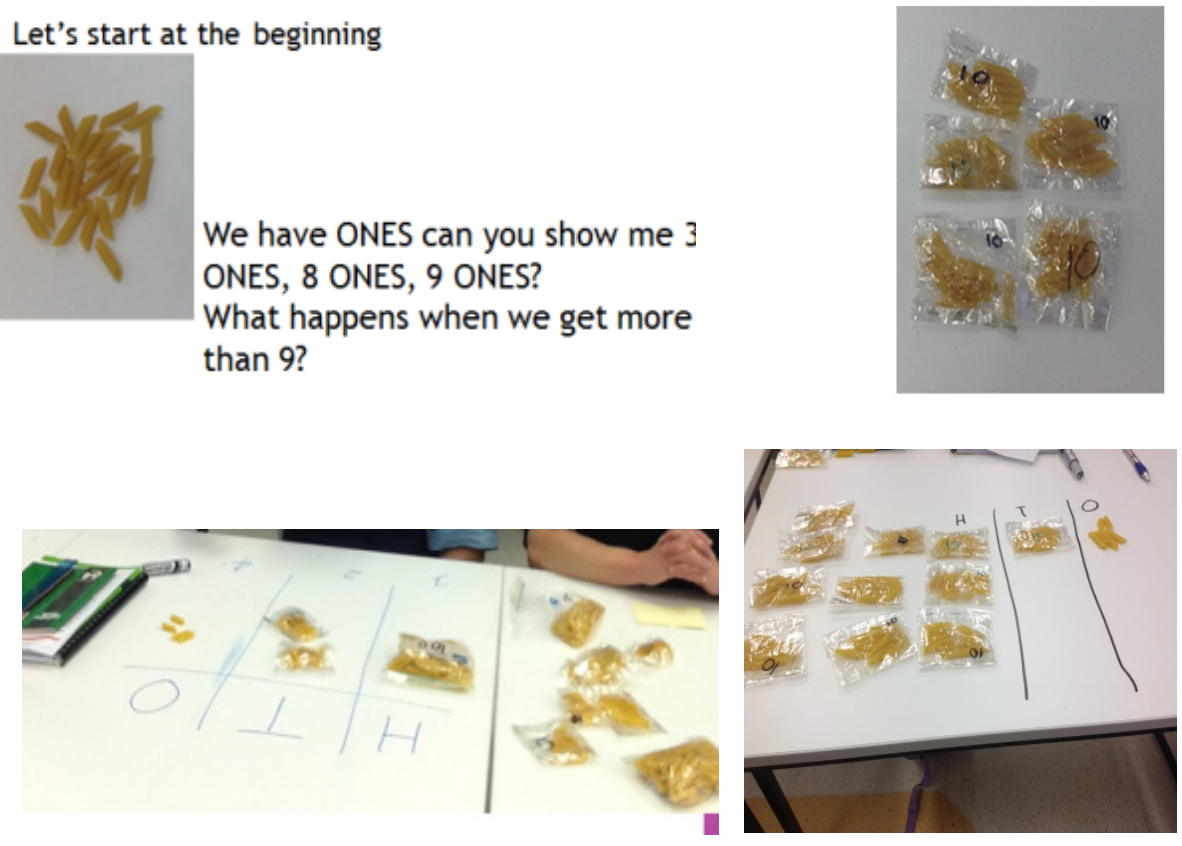

Figure 3. Example of renaming in place value
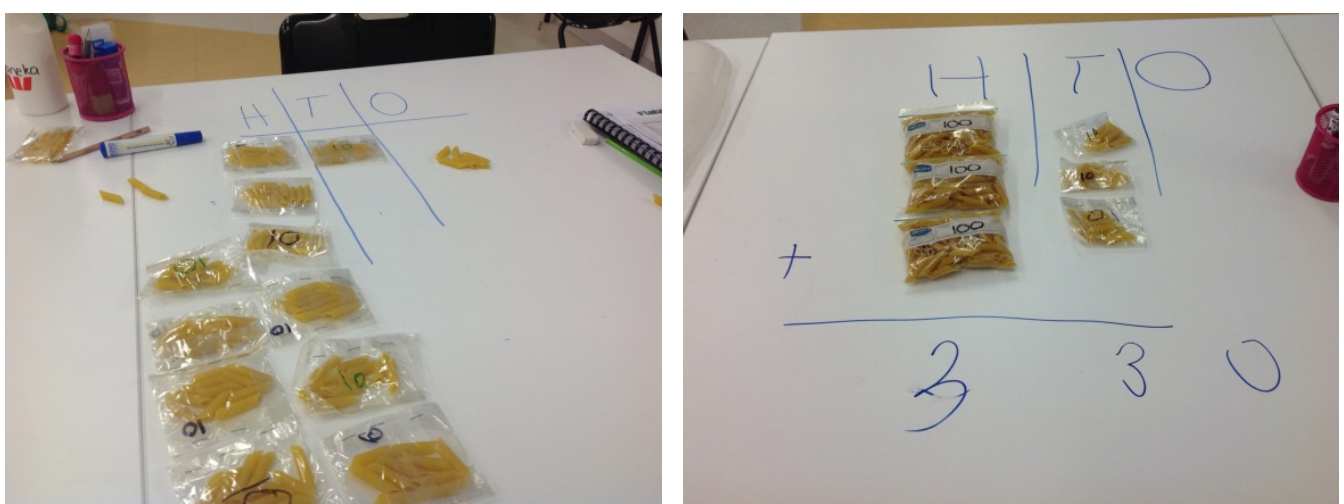

Figure 4. Students' representations of place value 
The intention of these questions was to specifically identify if students could rename 2-digit numbers in both directions (number -tens and ones; tens and ones -number). Talina reported that they could not. She then designed a teaching sequence that focus on renaming as part of place value learning. This sequence is presented graphically in figure 3 .

In this example Talina adopted a developmental approach to supporting students with learning about place value, in particular renaming. In this instance she drew on pasta (and small plastic bags) which was familiar to the students, captured their attention and provided opportunities for them to represent their developing knowledge and understanding about renaming. A significant outcome from using this approach was that students could represent their thinking as shown in figure 4.

In the following portfolio excerpt, Katrina reported that the purpose of the lesson sequence was to develop Year 5 students' confidence with number sequences. She drew on Year 1 and year 2 content descriptors of the Australian Mathematics Curriculum [28] -Year 1: Develop confidence with number sequences to and from 100 by ones from any starting point. Skip count by twos, fives and tens starting from zero; Year 2: Investigate number sequences, initially those increasing and decreasing by twos, threes, fives and ten from any starting point, then moving to other sequences.

\section{Reality: Counting}

As students could already count in $1 \mathrm{~s}$ to 100 and back, this term we were going to focus on counting on and back in $2 \mathrm{~s}$, $5 \mathrm{~s}$, and $10 \mathrm{~s}$ from any starting point.

Students participated in games such as 'leap frog' and 'kangaroo hop' that required them to jump over an object.

\section{Abstraction}

Students were introduced to the blank number grid. They practiced stepping or 'hopping' in every second grid space, ensuring that when they got to the end of the grid, they went back down to the other end and started along a new row.

Students then practiced stepping in every second grid space, dropping a counter in each space as they went along.

\section{Mathematics}

Appropriation: Students were asked to place the number symbols and language on the number grid. Practice: Just as students had practiced skipping along every second space on the blank number grid, they now practiced skipping along every second space on the grid, saying the number as they landed on it. Students were asked to relate the numeral to the position they were standing in along the number grid.

\section{Reflection}

Students practiced skip counting in twos across the duration of the term. They became very proficient in this skill. The fives and tens counting sequence was then introduced, using the same activities as outlined for the $2 \mathrm{~s}$ sequence. The threes sequence was introduced for two students.

\section{Teacher reflection on cycle}

Students were able to reach the point of being able to count on and back in $2 \mathrm{~s}$ from any starting point, some independently, some with assistance. Some students also had a go at counting in twos in odd numbers. Students also achieved well with the $10 \mathrm{~s}$ counting sequence. Approximately half of students have progressed with the $5 \mathrm{~s}$ sequence, however more practice is needed. Two students have progressed to learning the $3 \mathrm{~s}$ sequence.

Katrina's overall reflection about the implementation of the program was documented in two levels: 1) engagement and 2) confidence.

\section{Engagement levels}

Students were found to be highly engaged and enthusiastic about maths activities. Attention spans and levels of disengagement improved. Some of our students with Autism found group work on the floor, away from their desks a little difficult so visual symbols of tasks, "first this, then this" cards, and reward systems were put in place.

\section{Confidence levels}

Students were so excited to see their progress, and to know that at the beginning of the term they could only do 'this', but now at the end of the term, they could do 'THIS!' Individual learning goal charts were created for each student. Each time a student demonstrated the knowledge that we were aiming to gain, they would get a stamp on their chart. A filled up stamp chart $=$ a reward.

Central to Katrina's reflection were evaluative statements that worked to show the engagement and confidence of her students in their learning. For example the phrases, "highly engaged and enthusiastic", "so excited to see their progress", "they could do THIS!" worked to evaluate learning as desirable. They also worked to demonstrate possibilities for learning - talking about mathematics with students. Further the statements reveal the impact of the program on Katrina's planning for teaching of number to the students. Of significance was the statement, "attention spans and levels of disengagement improved". Here, the issue might not be so much about engagement and disengagement but rather about supporting students with learning how to talk and communicate mathematically in multi-sensory and multi-modal ways that closely match the classroom community. Over time, students are more likely to produce skilled talk and gain validation from Katrina and their peers as they demonstrate their understanding.

The data from the portfolios indicate that the experience of moving the PL to the school, classroom and students allowed the teachers to reconnect with their professional expertise. Clemans [35] reinforces this aspect by stating that this process facilitates the teachers making connections between their teaching, student learning in the classroom and the staffroom. It encourages the teachers to build on their professional strengths and practices that they use to engage 
learners and share these with their colleagues. Excerpts from the portfolios express these connections.

Staff and Students found this topic fun and exciting. Also found that since students enjoyed it so much, they seemed to understand concepts quickly.

Some positional Activities: Students chose a toy and I asked them to place in a drawer, under the chair, on the shelf, beside the sink etc. Introduced the idea of stepping over the chair and then under the table. The students then created their own obstacle course around the classroom. It was amazing to watch the students understand and self-direct their learning. (Portfolio, teacher, Karolina)

As Karolina made the connections between her teaching, other staff and the students' learning, she will be more readily able to "see" in the future how with increasing efficacy she will be able to weigh her perceptions of her teaching and personal competence. Past successes will strongly influence her expectations about herself, her staff and students as they learning about mathematics.

Able to expose students to broader concepts/big ideas through ... pedagogy. Still developing further means for pre-post assessment that is accessible for all students. Pedagogy allows for engagement of students at various levels throughout lessons

Students require further intervention to make links between reality/abstraction phase of learning and the mathematics. Continued work (at a school level) on frameworks/templates for recording planning.

Some students may have not shown vast development by moving through content, however their engagement and understanding of concepts appears to have been consolidated. Students may at times make links to previous learning experiences through other activities. (Portfolio, teacher, Katherine)

Past success and experience allows for making sense of teaching. Katherine shows that she is taking ownership of the implementation process in her own way. In doing so, the students' efficacy is showing to be affirmatively affected. When teachers like Katherine take an interest in and notice students' thinking and learning during mathematics lessons, transformations in teaching and learning occur.

Engagement levels: Students enjoyed the hands on, kinaesthetic activities to explore key concepts. Students responded well to the use of stories to help define key terminology. Some of our students with Autism found group work on the floor, away from their desks a little difficult so visual symbols of tasks, "first this, then this" cards, and reward systems were put in place.

Confidence levels: Students were more willing to try new activities and tasks as the cycle went on. All students had a go and enjoyed being praised and rewarded for their attempts. (Portfolio, teacher, Kalila)

So, too, does the teaching and learning environment get transformed. When students are engaged in multi-sensory learning to investigate and learning about mathematics as evidenced in Kalila response, their development of conceptual understandings of mathematical ideas and to use them, they are provided with efficacy information. This information is what sustains the motivation to keep teaching the kinds of lessons that are successful for students, increasing their efficacy as well.

Most students were unable to complete the Schedule Early Numeracy Assessment (SENA).

QCIA assessment was more successful as it allowed students to be assessed by using observation of hands on activities (anecdotal records, photographs and video) rather than pen-paper assessment.

RAMR cycle was helpful as a planning tool. All students were able to access the 'reality' and 'abstraction' phases. Some students had difficulty moving into the 'maths' phase.

All students had difficulty moving from body-> hand-> mind activities. All students needed to continually participate in body activities to meet their sensory needs. Some students experienced anxiety when being asked to complete worksheets or written activities and these needed to be modified to include a body activity.

Students had difficulty retaining information learned from one day to the next. Point in time assessment was unable to be used, rather students needed to show that they could complete the task on several different occasions to show that they had retained what they had learnt.

All students had difficulty generalizing the skills learnt. All lessons needed to be repeated in different locations and with different staff (both familiar and unfamiliar).

Continue our committee fortnightly meetings.

To assist with Diagnostic testing as such we will be trialling for the rest of 2015 using the Numeracy Indicators. This will include a comments section that will include the level of support the student requires to complete the task is recorded. There will be a colour code key which will include baseline data and then different colours for when the student progresses.

The four of us who participated in the project will become support staff for different areas of the school. (Portfolio, teacher, Shakira)

And finally, Shakira is confronted with the profound issues related to assessment for students with disability which fundamentally shaped the direction she would take with assessing student learning and planning for her teaching. 
She does appear to have confused the role of the SENA [see 36] as she implies that it is a pen and paper test, rather it is a diagnostic interview schedule. The importance of teachers like Shakira transitioning the knowledge and experience from the PL to her school, the staff and students was integral to the ways in which she would implement the program. She learnt about her role and the purpose of her work and developed effective approaches for collective transformations at her school.

\section{Discussion and Conclusions}

This interim reports has only focused on "snapshots" from the project to demonstrate its position about the achievement of students with disability and what can be achieved. Currently, there is limited research about students with disability, mathematics, multi-sensory and multimodal forms of learning and instructional pedagogy. Intervention studies of mathematics have focused on explicit instruction and concrete, abstract sequences of instruction [23, 37], but the literature is largely silent on the prior and existing knowledge and experiences of students with disability, how teachers can build on from that knowledge and experience and why this process is crucial to students' development and teachers' instructional strategies.

The preliminary evidence provided in the portfolios and excerpts in this report show that schools are actively participating and engaging in the project's implementation. The research evidence strongly indicates the increasing efficacy of teachers to take risks, test their hunches and ideas and collaboratively examine their work as well as the work of their colleagues and students. As a consequence of the project there are several implications for consideration.

It is highly likely that teachers are using a range of assessment strategies to assess student learning, mainly in number; however, whilst this is positive, for students who require a highly individualised curriculum and for whom intellectual disability is significant and requires extensive adjustments that are comprehensive and ongoing, there exists no suggested means of assessing what students know and are able to do in the large area of mathematics. This aspect is particularly evident in the portfolios. Furthermore, there currently exists no literature nor policy recommendation that advises schools as to the feasibility of administering diagnostic assessments in mathematics. What is known is that in current practice, schools take standard diagnostic assessments, intended for learners without intellectual disability, and individually modify these to ascertain student performance and to inform practice. Modifications are made on a teacher-by-teacher basis and often result in inconclusive results, leaving teachers to make assumptions about student performance. There is a considerable amount of work to be done in this area to ensure that teachers are better able to document student progress.

Efforts over the past decade to improve schools' mathematics performance have placed greater emphasis on students with disability to complete more challenging level. Given these expectations and the continued achievement difficulties students with disability experience, there is a need for special education teachers in the project to continue to build their repertoire of instructional strategies to assist students in their learning. The combination of wide-ranging deficits in foundational mathematics knowledge, experiences and skills and the pressure to increase student performance in the subject places students with disability at greater risk for failure unless specially designed instruction and resources are provided by their teachers.

In a new era where so much more is to be learned about how best to support special education teachers with teaching mathematics to students with disabilities, this interim report argues based on the PL, lesson modelling, questionnaire and portfolios submitted after Round 1 of the workshops in 2014, that a teacher who consistently exhibits a willingness to set challenges, persist with seeing them through and adopt new approaches to teaching, is highly likely to be effective with implementing the project more extensively and in doing so bring about successful for their students.

\section{Acknowledgements}

The implementation of the project was supported by the YuMi Deadly Centre staff at the Queensland University of Technology.

\section{REFERENCES}

[1] Department of Education. Disability Standards for Education: Australian Government; 2005 [29/09/2014]. Available from: http://education.gov.au/disability-standards-education.

[2] Australian Curriculum Reporting and Assessment Authority. Student diversity Melbourne: ACARA; 2013. Available from:

http://www.acara.edu.au/curriculum/student_diversity/studen t_diversity.html.

[3] Hammond S. The Thin Book of Appreciative Inquiry 1996. Available from:

http://www.thinbook.com/appreciative-inquiry/.

[4] Mills G. Action research: A guide for the teacher researcher. New Jersey: Merrill Prentice Hall; 2003. 46-73 p.

[5] Senate Standing Committee on Education and Employment. Access to real learning: the impact of policy, funding and culture on students with disability Canberra: Commonwealth of Australia; 2016 [22/01/2016]. Available from: http://www.csa.edu.au/documents/item/553.

[6] Organisation for Economic Cooperation and Development. Sickness, disability and work: Breaking the barriers-A synthesis of findings across OECD countries-OECD. Internationale Revue für Soziale Sicherheit. 2011;64(3):115-7. 
[7] Productivity Commission. Disability Care and Support. Productivity Commission Inquiry Report. No. 54, 312011 $[12 / 12 / 2015]$.

[8] Organisation for Economic Cooperation and Development. Sickness, disability and work Improving social and labour market integration of people with disability. 2011.

[9] Victorian Equal Opportunity \& Human Rights Commission. Held back: The experiences of students with disabilities in Victorian schools 2012 [25/11/2014]. Available from: www.humanrightscommission.vic.gov.au/.../1869_1f6729a0 8d2f6069a1.

[10] Ball DL, Thames, M H., \& Phelps, G.,. Content knowledge fo teaching: What makes it special. Journal of Teacher Education. 2008;59:389-407.

[11] Lannin J, Webb, M., Chval, K., Arbaugh, F., Hicks, S., Taylor, C., \& Bruton, R. The development of beginning mathematics teacher pedagogical content knowledge. Journal of Mathematics Teacher Education. 2013.

[12] Browder DM, Spooner F, Ahlgrim-Delzell L, Harris AA, Wakeman S. A Meta-Analysis on Teaching Mathematics to Students With Significant Cognitive Disabilities. Exceptional children. 2008;74(4):407-32.

[13] Hunt JH, Valentine C, Bryant DP, Pfannenstiel KH, Bryant BR. Supplemental Mathematics Intervention: How and Why Special Educators Intensify Intervention for Students With Learning Disabilities. Remedial and Special Education. 2016;37(2):78-88.

[14] Bryant DP, Bryant BR, Roberts G, Vaughn S, Pfannenstiel $\mathrm{KH}$, Porterfield $\mathrm{J}$, et al. Early Numeracy Intervention Program for First-Grade Students with Mathematics Difficulties. Exceptional children. 2011;78(1):7-23.

[15] Ewing B, Sarra, G., Cooper, T. J., \& Matthews, C. Successful outcomes in vocational education and training courses and mathematics: How pedagogy and expectations influence achievement. 2014. In: Changing Configurations in Adult Education in Transitional Times International Perspectives in Different Countries [Internet]. Berlin: European Society for Research on the Education of Adults; [307-27].

[16] Ewing BF, Cooper, T. J., Baturo, A. R., Matthews, C., \& Sun, H. Contextualising the teaching and learning of measurement within Torres Strait Islander schools. Australian Journal of Indigenous Education. 2010;39:11-23.

[17] Baturo A. Developing mathematics understanding through cognitive diagnostic assessment tasks. Canberra: Department of Education, Employment and Workplace Relations; 2008.

[18] Cooper TJ, Baturo AR, Ewing BF, Duus E, Moore KM. Mathematics education and Torres Islander blocklaying students: The power of vocational context and structural understanding. In J. Woo, H. Lew, K. Park, \& D Seo (Eds.) Proceedings of 31st Annual Conference of the International Group for the Psychology of Mathematics Education. (Vol 2, pp. 177-184) Seoul, South Korea: Seoul National University. 2007.

[19] Queensland Government. Great results guarantee 2014. Available from: http://education.qld.gov.au/schools/grants/st ate/targeted/great-results.html.
[20] Department of Education and Training. 2014. Available from: https://www.studentsfirst.gov.au/.

[21] Payne J, \& Rathmell, E.,. Number and Numeration'. In: Payne JN, editor. Mathematics learning in early childhood. Reston VA: National Council for Teachers of Mathematics; 1975. p. 125-60.

[22] Bruner J. The process of education. Cambridge, Mass: Harvard University Press; 1960.

[23] Witzel BS, Riccomini PJ, Schneider E. Implementing CRA With Secondary Students With Learning Disabilities in Mathematics. Intervention in School and Clinic. 2008;43(5):270-6.

[24] White P, \& Mitchelmore, M. Teaching and learning mathematics by abstraction. In: Thomas TTM, editor. Intelligence, learning and understanding in mathematics: A tribute to Richard Skemp. Flaxton: Post Pressed; 2002.

[25] Voigt J. Negotiation of mathematical meaning and learning mathematics. In: Cobb P, \& Yackel, E., editor. Learning mathematics: Constructivist and interactionist theories of mathematics development. Dordrecht: Kluwer Academic Publishers; 1994. p. 171-94.

[26] Davis R, \& Dart, J. The "Most Significant Change"' (MSC) Technique 2005 [updated 01/10/2015]. Available from: http://www.mande.co.uk/docs/MSCGuide.pdf.

[27] Ford N, \& Ashford, G.,. Appreciative inquiry Ottawa, Ontario: Participatory Development Forum; 2000. Available from: http://www.pdforum.org/eviews1.html

[28] Australian Curriculum Reporting and Assessment Authority. Foundation to Year 10 Mathematics 2011 [23/11/2012]. Available from: http://www.australiancurriculum.edu.au/mat hematics/curriculum/f-10?layout=1.

[29] Department of Employment. Labour market research - school teachers: Department of Employment, Australian Government; 2015 [12/03/2016]. Available from: https://docs.employment.gov.au/system/files/doc/other/schoo lteachersaus.pdf.

[30] Jeltova I, Birney D, Fredine N, Jarvin L, Sternberg RJ, Grigorenko EL. Making Instruction and Assessment Responsive to Diverse Students' Progress: Group-Administered Dynamic Assessment in Teaching Mathematics. Journal of Learning Disabilities. 2011;44(4):381-95.

[31] Gabriele AJ, \& Joram E.,. Teachers' reflections on their reorm-based teaching in mathematics: Implications for the development of teacher self-efficacy. Action Teacher Education. 2007;29(3):60-79.

[32] Jitendra AK. Understanding and Accessing Standards-Based Mathematics for Students with Mathematics Difficulties. Learning Disability Quarterly. 2013;36(1):4-8.

[33] Lembke ES, Hampton D, Beyers SJ. Response to intervention in mathematics: Critical elements. Psychology in the Schools. 2012;49(3):257-72.

[34] Powell SR, Fuchs LS, Fuchs D. Reaching the Mountaintop: Addressing the Common Core Standards in Mathematics for Students with Mathematics Difficulties. Learning Disabilities Research \& Practice. 2013;28(1):38-48. 
[35] Clemans A, Berry A, Loughran J. Lost and found in transition: the professional journey of teacher educators. Professional Development in Education. 2010;36(1-2):211-28.
[36] Wright RJ, Martland J, Stafford A. Early Numeracy: Assessment for Teaching and Intervention. First ed. London: Sage Publications Inc; 2006. 198 p.

[37] Doabler CT, Fien H. Explicit Mathematics Instruction: What Teachers Can Do for Teaching Students With Mathematics Difficulties. Intervention in School and Clinic. 2013;48(5):276-85. 